\section{Inheritance of Growth Habit and Qualitative Flowering Response in Lima Beans (Phaseolus lunatus L.)}

\author{
H.T. Erickson \\ Horticulture Department, Purdue University, West Lafayette, IN 47907
}

Additional index wordplant genetics, epistasis, environment-genetic interaction, evolution, lethals, photoperiod

\begin{abstract}
Indeterminate growth habit in lima bean is inherited as a single gene dominant. A qualitative short-day photoperiodic response for flowering appears to be controlled by duplicate dominant genes with coupling linkage to the gene for growth habit. Partial epistasis of the determinate growth habit on genes for short-day response is suggested.
\end{abstract}

Accessions of tropical South American lima beans typically require short photoperiods for flower production and have an indeterminate viny growth habit. I found no detailed genetic analysis of the inheritance of these traits in the literature. When hybridized with dayneutral, determinate cultivars, the tropical phenotype is dominant in the $\mathrm{F}$,. Complementary dominant genes were shown to control a quantitative short-day response in $\mathbf{P}$. vulgaris $\mathrm{L}$. with expression modified by temperature (Coyne, 1967). A single dominant gene gave indeterminate growth. Coupling linkage was reported to occur between genes controlling determinate plant habit and early flowering, with an estimated crossover value of $8.4 \%$ (Coyne and Schuster, 1974).

The investigation reported here presents evidence for a similar pattern of inheritance of flowering response to photoperiod in lima beans. Flowering response in lima beans has been characterized as day neutral and qualitatively short day (Salisbury, 1963). Harding et al. (1981) described the presence of quantitative responses as well. All short-day parents in the present study are qualitative, with an apparent absolute requirement for photoperiods of $\leq 12 \mathrm{~h}$.

Five $\mathrm{F}_{2}$ families of day-neutral, determinate $\times$ short-day, indeterminate parents were field grown during five summers at Lafayette, Ind. Parent lines are presented in Table 1. Plantings were made the first week of June and segregating populations classified for flowering response from mid- to late August, beginning 1 month after anthesis in day-neutral parents. Seeds were planted at $\approx 30-\mathrm{cm}$ intervals to reduce interplant competition and to facilitate accurate scoring of the segregants. Greenhouse populations of two of these

Received for publication 7 Feb. 1991. Accepted for publication 27 Sept. 1991. Purdue Univ. Agricultural Experiment Station Journal Paper no. 12,847 . Mention of trade names in this publication does not imply endorsement by the Purdue Agricultural Experiment Station of products named, nor criticism of similar ones not named. The cost of publishing this paper was defrayed in part by the payment of page charges. Under postal regulations, this paper therefore must be hereby marked advertisement solely to indicate this fact. families were grown in 2-liter plastic pots from late winter to early summer under an 18-h photoperiod and scored over an extended period of increasing ambient temperature, with maxima ranging from 23 to $37 \mathrm{C}$.

Field segregation of two families agrees with single-gene dominant control of indeterminate growth habit (Table 2). The other
Table 1. Origin and characteristics of lima bean parents.

'U.S. Dept. Agriculture Plant Inventory number. (3:1 ratio) in lima bean crosses. crosses of lima beans. plants recessive for one or both alleles are day neutral. three families had an excess of determinate plants; however, one, P-10 x BGH 273, gave a nonsignificant $x^{2}$ in a greenhouse population. All families except 'Bridgeton' x BGH 838 had from $15 \%$ to $20 \%$ lethal and "cripple" plants similar to those described by Coyne (1965) in P. vulgaris. In the field, most of these plants either died as seedlings or could not be classified reliably. Their presence would have skewed the progeny distribution if nonrandomly associated with the traits being scored. The consistent excess of determinate plants suggests this possibility. In the greenhouse, most stunted plants survived long enough to allow phenotypic classification. Finke et al. (1986) postulated a three-gene additive model to explain the segregation of normal and crippled plants in a study involving $P$. vulgaris parents of diverse origin. Inheritance of the cripple condition was not critically studied in my tests.

A 9:7 ratio gave the best fit for field segregation of flowering, although two families have very highly significant $x^{2}$; short-day segregants-were in excess in each case (Table 3). Greenhouse populations, in contrast, provided a good fit to a 9:7 ratio. If there is selective deficiency of day-neutral plants due

\begin{tabular}{lllcll}
\hline \hline & & & \multicolumn{2}{c}{ Plant type } \\
${ } }$ & PI no. & Origin & Seeds $/ \mathrm{kg}$ & Growth habit & Photoperiod \\
\hline P-10 & & United States & 3150 & Determinate & Day-neutral \\
Bridgeton & & United States & 3180 & Determinate & Day-neutral \\
Manteiga & & Brazil & 2100 & Indeterminate & Short-day \\
BGH 273 & 362770 & Brazil & 400 & Indeterminate & Short-day \\
BGH 275 & 362771 & Brazil & 820 & Indeterminate & Short-day \\
BGH 836x & 362798 & Brazil & 2240 & Indeterminate & Short-day \\
BGH 838 & 362800 & Brazil & 1270 & Indeterminate & Short-day \\
\hline
\end{tabular}

${ }^{2}$ BGH is the designation for entries in a collections at Vicosa, Minas Gerais, Brazil.

"Accessions that segregated for "crippled" plants in crosses with P-10.

Table 2. $\mathrm{F}_{2}$ segregation for indeterminate vs. determinate plant type assuming a single gene difference

\begin{tabular}{lcccc}
\hline \hline & \multicolumn{2}{c}{ Phenotypes } & & \\
\cline { 2 - 4 } Cross $^{\mathrm{z}}$ & Indeterminate & Determinate & \multicolumn{1}{c}{$\chi^{2}$} & $P$ \\
\hline P-10 $\times$ BGH 836 & 1645 & 632 & 9.29 & $<0.01$ \\
\hline P-10 $\times$ Manteiga & 341 & 169 & 17.53 & $<0.001$ \\
$\overline{\text { P-10 }}$ BGH 273 & 681 & 268 & 5.40 & $<0.05$ \\
(greenhouse) & 200 & 79 & 1.55 & $>0.20$ \\
P-10 $\times$ BGH 275 & 812 & 285 & 0.58 & $>0.40$ \\
Bridgeton $\times$ BGH 838 & 264 & 83 & 0.24 & $>0.50$ \\
(greenhouse) & 219 & 69 & 0.16 & $>0.70$ \\
\hline
\end{tabular}

${ }^{2}$ Day-neutral determinate parents are underlined. Plants were field-grown, except as indicated.

Table 3. F, segregation for flowering due to a photoperiod response (short-day vs. day-neutral) in

\begin{tabular}{lcccc}
\hline \hline & \multicolumn{2}{c}{ Phenotypes } & & \\
\cline { 2 - 4 } Cross $^{2, y}$ & Short-day & Day-neutral & $\chi^{2}$ & $P$ \\
\hline P-10 $\times$ BGH 836 & 1290 & 987 & 0.14 & $>0.90$ \\
P-10 $\times$ Manteiga & 297 & 213 & 0.96 & $>0.30$ \\
P-10 $\times$ BGH 273 & 591 & 358 & 13.91 & $<0.001$ \\
(greenhouse) & 166 & 113 & 1.18 & $>0.25$ \\
P-10 $\times$ BGH 275 & 712 & 385 & 33.43 & $<0.001$ \\
Bridgeton $\times$ BGH 838 & 214 & 133 & 4.22 & $<0.05$ \\
(greenhouse) & 161 & 127 & 0.01 & $>0.90$ \\
\hline
\end{tabular}

${ }^{2}$ Day-neutral determinate parents are underlined. Plants were field-grown, except as indicated.

${ }^{\mathrm{y}} \mathrm{x}$ are calculated for a 9:7 ratio where two complementary dominant genes give a short-day response; 
Table 4. Distribution of parental and recombinant phenotypes in $\mathrm{F}_{2}$ progeny of five day-neutral determinate $\mathrm{x}$ short-day indeterminate lima bean hybrids. $x^{2}$ test for independence $(\mathrm{df}=1)$. Deviations $(\%)$ from expected appear in parentheses.

\begin{tabular}{|c|c|c|c|c|c|c|c|}
\hline \multirow[b]{2}{*}{ Cross $^{2}$} & & \multicolumn{2}{|c|}{ Parental } & \multicolumn{2}{|c|}{ Recombinant } & \multirow[b]{2}{*}{$x^{2}$} & \multirow[b]{2}{*}{$P$} \\
\hline & & $\begin{array}{c}\text { Indeterminate } \\
\text { short-day }\end{array}$ & $\begin{array}{l}\text { Determinate } \\
\text { day-neutral }\end{array}$ & $\begin{array}{c}\text { Indeterminate } \\
\text { day-neutral }\end{array}$ & $\begin{array}{c}\text { Determinate } \\
\text { short-day }\end{array}$ & & \\
\hline$\underline{\mathrm{P}-10} \times \mathrm{BGH} 273$ & $\begin{array}{l}\mathrm{O} \\
\mathrm{E}\end{array}$ & $\begin{array}{l}671(24) \\
543\end{array}$ & $\begin{array}{l}261(96) \\
133\end{array}$ & $\begin{array}{l}210(-60) \\
338\end{array}$ & $\begin{array}{l}86(-149) \\
214\end{array}$ & 278.38 & $<0.001$ \\
\hline$\frac{\text { P-10 }}{\text { (greenhouse) }}$ & $\begin{array}{l}\mathrm{O} \\
\mathrm{E}\end{array}$ & $\begin{array}{l}154(29) \\
119\end{array}$ & $\begin{array}{l}67(109) \\
32\end{array}$ & $\begin{array}{l}46(-76) \\
81\end{array}$ & $\begin{array}{l}12(-292) \\
47\end{array}$ & 89.76 & $<0.001$ \\
\hline$\underline{\mathrm{P}-10} \times \mathrm{BGH} 836$ & $\begin{array}{l}\mathrm{O} \\
\mathrm{E}\end{array}$ & $\begin{array}{c}1143(23) \\
932\end{array}$ & $\begin{array}{l}485(77) \\
274\end{array}$ & $\begin{array}{l}502(-42) \\
713\end{array}$ & $\begin{array}{l}147(-143) \\
358\end{array}$ & 397.05 & $<0.001$ \\
\hline$\underline{\mathrm{P}-10} \times$ Manteiga & $\begin{array}{l}\mathrm{O} \\
\mathrm{E}\end{array}$ & $\begin{array}{l}246(24) \\
199\end{array}$ & $\begin{array}{l}118(66) \\
71\end{array}$ & $\begin{array}{l}95(-49) \\
142\end{array}$ & $51(-78)$ & 80.31 & $<0.001$ \\
\hline$\underline{\mathrm{P}-10} \times$ BGH 275 & $\begin{array}{l}\mathrm{O} \\
\mathrm{E}\end{array}$ & $\begin{array}{l}610(16) \\
528\end{array}$ & $\begin{array}{l}183 \\
100\end{array}$ & $\begin{array}{l}202(-40) \\
284\end{array}$ & $\begin{array}{l}102(-81) \\
185\end{array}$ & 142.54 & $<0.001$ \\
\hline Bridgeton $\times$ BGH 838 & $\begin{array}{l}\mathrm{O} \\
\mathrm{E}\end{array}$ & $\begin{array}{l}198(23) \\
161\end{array}$ & $\begin{array}{l}69(116) \\
32\end{array}$ & $\begin{array}{l}66(-56) \\
103\end{array}$ & $\begin{array}{l}14(-264) \\
51\end{array}$ & 91.41 & $<0.001$ \\
\hline$\frac{\text { Bridgeton }}{\text { (greenhouse) }}$ & $\begin{array}{l}\mathrm{O} \\
\mathrm{E}\end{array}$ & $\begin{array}{l}157(29) \\
122\end{array}$ & $\begin{array}{l}65(116) \\
30\end{array}$ & $\begin{array}{l}62(-55) \\
96\end{array}$ & $\begin{array}{r}4(-850) \\
38\end{array}$ & 93.27 & $<0.001$ \\
\hline
\end{tabular}

${ }^{2}$ Day-neutral determinate parents are underlined.

Table 5. Segregation for flowering due to a photoperiod response of $\mathrm{F}_{3}$ lima bean families from determinate, short-day selfed $\mathrm{F}_{2}$ selections of Bridgeton x BGH $838\left(\mathrm{~F}_{2}\right)$.

\begin{tabular}{cccccc}
\hline \hline Family & Short-day & Day-neutral & Ratio & $\chi^{2}$ & $P$ \\
\hline 1 & 40 & 42 & $9: 7$ & 1.78 & $>0.10$ \\
2 & 13 & 3 & $3: 1$ & 0.33 & $>0.50$ \\
3 & 8 & 7 & $9: 7$ & 0.27 & $>0.50$ \\
4 & 9 & 6 & $9: 7$ & 0.09 & $>0.75$ \\
\hline
\end{tabular}

to the presence of lethals, the pattern was not consistent. The large P-10 x BGH 836 $\mathrm{F}_{2}$ family, for example, showed excellent agreement to a 9:7 ratio, and it has lethals. The indeterminate parents represented a heterogeneous array of accessions (Erickson, 1982), and it is possible that genetic modifiers exist for the traits themselves and, further, any associations with lethal factors could vary among populations.

Plant photoperiodic response can be modified by temperature. Delayed flowering of some common bean (P. vulgaris) cultivars was associated with high temperatures (Coyne, 1970). Leyna et al. (1982) suggested that under lower night temperatures, a single gene for delayed flowering was activated, whereas more than one gene was activated under high temperature. This temperature $\mathrm{x}$ photoperiod interaction concept was further refined to include two gene systems (D.H. Wallace, communication at the W-150 Regional Project Meeting, Michigan State Univ., 1986). Gene system 1 relates to the number of nodes produced before the first flower bud was visible (node to first flower), which increases with mean temperature in photoperiodically sensitive plants and can give delayed flowering at high temperatures. Gene system 2 relates to rate of node development and is temperature sensitive independent of photoperiod, giving earlier flowering at increasing temperatures. Harding et al. (1981) reported on photoperiodic reaction in qualitative and quantitative day-length-responsive lima beans. They found that nodes to first flower was often related to a specific number of daylight hours, within the photoperiodic range that permitted flowering. This response varied among cultivars. They concluded that genetic control of response to photoperiod may be complex.

From the foregoing, it is apparent that environment $\times$ genotype interaction and/or the presence of lethals could have influenced the segregation ratios obtained in this study. All short-day parents and $\mathrm{F}_{1}$ hybrids were qualitative, or discontinuous, short-day plants, i.e., they failed to flower under any observed environmental condition that exceeded $\approx 12$ $\mathrm{h}$ of light. These perennial plants have remained vegetative for several years in the greenhouse under long-day regimes that included reduced light intensity and temperature in the winter and high temperature and intense light in the summer. In this respect, they differ from the $P$. vulgaris studies referred to above, where flowering eventually occurred under long days in the field or in controlled-climate chambers. Segregating $\mathrm{F}_{2}$ progenies would have incorporated any quantitative genes for photoperiod and or photoperiod-temperature interactions that may have been present in the parents, giving delayed flowering in the field under long days, and these may have been erroneously classified as qualitative short-day plants, accounting for their recorded excess. Data in a greenhouse were collected over 3 months following anthesis of the earliest plant, under a constant 18-h photoperiod, increasing the likelihood of detecting segregants with greatly delayed flowering. These then would have been correctly classified as day neutral, according to the criterion used in this study. Greenhouse populations, and progenies of 'Bridgeton' parentage, where lethals were absent, would seem to provide the most reliable data and indeed are in closest agreement with expected ratios.

Evidence points to a single dominant major gene for indeterminate growth habit and to complementary dominant genes for a shortday photoperiodic response, despite observed ambiguity in some field-grown populations. An excess of parental types over recombinants suggests coupling phase linkage between the gene for day-neutral response to photoperiod and determinate growth habit (Table 4). This excess of parental types occurs in each family. Epistasis of determinate habit on genes for short-day response was reported for P. aborigineus Burkhart by Rudorf (19.58) and incomplete epistasis was found in P. vulgaris by Coyne (1967). Evidence for epistasis is seen in the proportionate excess of day-netural determinate segregants and the deficiency of short-day determinates in most crosses, relative to their companion parental and recombinant classes. Phenotypically, short-day determinate plants have tiny peg-like terminal inflorescences that fail to develop beyond a rudimentary bud stage under long days.

Four $\mathrm{F}_{3}$ families derived from determinate, short-day segregants of 'Bridgeton' $\mathrm{x}$ BGH $838\left(\mathrm{~F}_{2}\right)$ segregated for flowering in normal 3:1 or 9:7 ratios (Table 5). Populations were small but all agreed with the twogene model, with segregation for either one (3:1) or both (9:7) genes. These data do not implicate the epistatic effect suggested above. Homozygous determinate, short-day lines have been developed from them and will be available for research purposes.

It is fortuitous from a plant breeding standpoint that the proportion of determinate day-neutral segregants is relatively large as a consequence of the apparent coupling-phase linkage and possible epistasis. Large populations of plant types adapted to temperate climates can be readily obtained from segregating populations of these widely divergent parents. About $20 \%$ of $\mathrm{F}_{2}$ segregants are homozygous determinant day neutral, and this facilitates introgression of exotic germplasm into a commercial type background.

Phaseolus vulgaris and P. Iunatus are totally isolated from one another reproductively. Yet despite evolutionary divergence, the inheritance of growth habit and photoperiod appears to have been conserved, even 
to the extent that similar linkage for the traits seems to exist in the two species. It should be emphasized, however, that this study addresses a qualitative photoperiodic response; comparison with the $P$. vulgaris studies involving a quantitative response may not be valid.

\section{Literature Cited}

Coyne, D.P. 1965. A genetic study of "crippled" morphology resembling virus symptoms in Phaseolus vulgaris L. J. Hered. 56:162-163.

Coyne, D.P. 1967. Photoperiodism: Inheritance and linkage studies in Phaseolus vulgaris. J. Hered. 58:313-314.
Coyne, D.P. 1970. Genetic control of a photoperiodic-temperature response for time of flowering in beans Phaseolus vulgaris. Crop Sci. 10:246-248

Coyne, D.P. and M.L. Schuster. 1974. Inheritance and linkage relations of reaction to Xanthomonas phaseoli (E.F. Smith) Dowson (common blight), stage of plant development and plant habit in Phaseolus vulgaris L. Euphytica 23:195-204.

Erickson, H.T. 1982. Lima bean legacy. HortScience 17:702.

Finke, M.L., D.P. Coyne, and J.R. Steadman. 1986. The inheritance and association of resistance to rust, common bacterial blight, plant habit and foliar abnormalities in Phaseolus vulgaris L. Euphytica 35:969-982.

Harding, J., C.L. Tucker, and K. Barnes. 1981. Genetic variation for flowering response to photoperiod in Phaseolus lunatus L. J. Amer. Soc. Hort. Sci. 106:69-72.

Leyna, H.K., S.S. Korban, and D.P. Coyne. 1982. Changes in patterns of inheritance of flowering time of dry beans in different environments. J. Hered. 73:306-308.

Rudorf, W. 1958. Genetics of Phaseolus aborigineus Burkart. Proc. 10th Intl. Congr. Genet. 2:243.

Salisbury, F.B. 1963. The flowering process. Macmillan, New York. p. 207-215. 